\title{
HUBUNGAN PENGETAHUAN TENTANG GROWTH SPURT DENGAN SIKAP IBU MENYUSUI DALAM PEMBERIAN ASI PADA BAYI USIA 7-10 HARI
}

\author{
Evvin Faristasari ${ }^{1}$, Siswi Wulandari ${ }^{2}$, Fita Avrista Vilusi Amin ${ }^{2}$ \\ ${ }^{1}$ UIN Maulana Malik Ibrahim Malang \\ ${ }^{2}$ Universitas Kadiri \\ E-mail: evvin.faristasari@gmail.com; wulandarisiswi@gmail.com;
}

fiethalovely23@gmail.com.

\begin{abstract}
Background: Many factors have an effect on exclusive breastfeeding failure. For example, the term ASI is not enough, here the maternal factor is the main role in breastfeeding the baby. At a certain age the baby experiences growth spurt or abbreviated GS. Infants accelerate growth at 7-10 days, 2-3 weeks, 4-6 weeks, 3 months, 6 months, 9 months or more, or at other times. One of the hospitals in this city is one of the mother and child hospital in the City of Malang which has a policy of merger facilities between the mother and her newborn baby. This policy can directly support the process of breastfeeding exclusively. Research Method: This research is correlational analytic. Characteristics of respondents in this study were classified based on maternal age, maternal education, and maternal parity. There were 30 respondents who participated in this study. Result : The result of cross tabulation can be seen that $\mathrm{p}$-value $<\alpha(0,024<0,05)$ and concluded that Ho is rejected and $\mathrm{H} 1$ is accepted which states that there is a relationship of knowledge about growth spurt (acceleration of growth) with the attitude of breastfeeding mothers in breastfeeding infants aged 7- 10 days with a confidence level of 95\%. Conclusion: the level of maternal knowledge about growth spurt is related to the attitude of breastfeeding mothers in breastfeeding in infants aged 7-10 days.
\end{abstract}

Keywords: growth spurt, Mother and child hospital, exclusive breastfeeding, breastfeeding attitudes

\begin{abstract}
Abstrak
Latar belakang: Banyak faktor yang berpengaruh dalam kegagalan ASI eksklusif. Misalnya istilah ASI tidak cukup, disini faktor ibu adalah peran utama dalam pemberian ASI kepada buah hatinya. Pada usia tertentu bayi mengalami percepatan pertumbuhan (growth spurt) atau disingkat GS. Bayi mengalami percepatan pertumbuhan pada usia 7-10 hari, 2-3 minggu, 4-6 minggu, 3 bulan, 6 bulan, 9 bulan atau lebih, atau bisa juga di waktu-waktu yang lainnya. Salah satu RSIA di Kota Malang ini memiliki kebijakan fasilitas rawat gabung antara ibu dan bayinya yang baru dilahirkan. Kebijakan ini secara langsung dapat mendukung proses pemberian ASI secara ekslusif. Metode Penelitian: penelitian ini merupakan analitik korelasional. Karakteristik responden dalam penelitian ini diklasifikasikan berdasarkan usia $\mathrm{ibu}$, pendidikan ibu, dan paritas ibu. Terdapat 30 responden yang ikut serta dalam penelitian ini. Hasil: Hasil tabulasi silang dapat diketahui bahwa $p$-value $<\alpha(0,024<0,05)$ dan simpulkan Ho ditolak dan H1 diterima yang menyatakan bahwa ada hubungan pengetahuan tentang growth spurt (percepatan pertumbuhan) dengan sikap ibu menyusui dalam pemberian asi pada bayi usia 7-10 hari dengan tingkat kepercayaan sebesar $95 \%$. Kesimpulan: tingkat pengetahuan ibu tentang growth spurt berhubungan dengan sikap ibu menyusui dalam pemberian asi pada bayi usia 7-10 hari.
\end{abstract}

Kata Kunci : growth spurt, RSIA, ASI eksklusif, sikap ibu menyusui 


\section{PENDAHULUAN}

Percepatan pertumbuhan (growth spurt) tidak hanya terjadi pada bayi, tetapi hal ini akan terus terjadi sampai bayi menjadi seorang remaja. Tetapi, pada bayi kondisi ini berlangsung \pm 3 hari dan terjadi di usia 10-14 hari, 3 minggu, 6 minggu, 3 bulan, 6 bulan dan 9 bulan. Pada masa ini, bayi mengalami pertumbuhan dan perkembangan fisik dan mental yang sangat cepat, sehingga membutuhkan ekstra kalori untuk mengimbanginya. Pada bayi ASI, ekstra kalori tersebut didapat dengan cara meningkatkan produksi ASI ibunya dan cara yang paling ampuh untuk meningkatkan produksi ASI adalah dengan bayi lebih sering menyusu. ${ }^{1}$

ASI merupakan nutrisi paling lengkap yang diterima bayi usia 0-6 bulan dan memiliki beberapa faktor pelindung terhadap infeksi. ${ }^{2}$ Manfaat ASI begitu banyak. Cairan "emas" ini merupakan hadiah yang luar biasa bagi ibu dan bayi. Alangkah sayangnya jika ASI ini tidak diberikan ke bayi yang sangat membutuhkan untuk tumbuh kembangnya. Menurut UndangUndang Republik Indonesia nomor 36 tahun 2009 Tentang Kesehatan, terkait ASI terdapat pada pasal 128, memuat : setiap bayi berhak mendapatkan ASI eksklusif sejak dilahirkan selama 6 (enam) bulan, kecuali atas indikasi medis. Pemberian ASI eksklusif bagi bayi dapat meningkatkan daya tahan tubuh karena mengandung berbagai zat kekebalan bayi terutama selama minggu pertama (4-6 hari) pada kolostrum sehingga akan lebih jarang sakit ${ }^{3}$. ASI meningkatkan sistem kekebalan tubuh bayi. Ibu meneruskan zat antibodi mereka lewat ASI kepada bayi-bayi mereka, sehingga bayi dapat membentuk sistem pertahanan tubuh yang kuat untuk melawan virus flu dan infeksi. ${ }^{4}$

Berdasarkan data dari WHO pada tahun 2016 menunjukkan, cakupan ASI eksklusif di seluruh dunia hanya sekitar 36\% selama periode 2007-2014. Berdasarkan laporan SDKI tahun 2012 di Indonesia dari 96\% ibu menyusui hanya 42\% yang berhasil memberi ASI eksklusif hingga bayi berusia 6 bulan. Indikator keberhasilan pembangunan kesehatan antar lain adalah penurunan angka kematian bayi dan peningkatan status gizi masyarakat. Hal ini berkaitan dengan target MDG's (Millenium Development Goals) yang ke 4 yaitu untuk menurunkan angka kematian bayi hingga dua pertiganya per 1000 kelahiran hidup dalam kurun waktu 1990-2015. ${ }^{5}$ Berdasarkan data profil kesehatan Indonesia tahun 2014, jumlah bayi di Indonesia dalam rentang usia 0-6 bulan adalah sekitar 2.000.200 bayi, sedangkan yang mendapat ASI eksklusif hanya 1.046 .173 bayi atau hanya 52,3\%. ${ }^{6}$ Pemberian ASI eksklusif terhadap bayi baru lahir masih rendah di Kota Malang. Pada tahun 2016 terjadi penurunan dalam pemberian ASI eksklusif jika dibandingkan dengan tahun 2015. Pada tahun 2015 pemberian ASI eksklusif mencapai 79,12\%. Sedangkan pada tahun 2016 pemberian 
ASI eksklusif menurun menjadi 75,27\% dari 8277 bayi, sehingga jumlah bayi yang diberi ASI eksklusif adalah 6230 bayi. $^{7}$

Banyak faktor yang berpengaruh dalam kegagalan pemberian ASI eksklusif. Misalnya istilah ASI tidak cukup, disini faktor ibu adalah peran utama dalam pemberian ASI kepada buah hatinya. Informasi begitu banyak di zaman modern ini, tergantung individu itu sendiri mau menggali lebih dalam atau tidak. Keinginan untuk memberikan ASI eksklusif sebagian besar telah dimiliki ibu sejak hamil. Tidak terdapat perbedaan yang berarti antara intensi ibu pekerja sektor formal maupun informal. Intensi ibu untuk memberikan ASI eksklusif timbul setelah mendapatkan informasi dan pengetahuan dari pertemuan KP (kelompok pendukung) ibu, pelatihan pemberian ASI eksklusif, buku panduan kehamilan, tenaga kesehatan, dan internet. $^{5}$

Kecemasan ibu pada jumlah ASI yang dimiliki dapat menghambat keberhasilan ASI ekslusif. Bayi hanya minum ASI saja selama 6 bulan penuh tanpa tambahan makanan/minuman lainnya. Pada usia tertentu bayi mengalami percepatan pertumbuhan (growth spurt) atau disingkat GS. Bayi mengalami percepatan pertumbuhan pada usia 7-10 hari, 2-3 minggu, 4-6 minggu, 3 bulan, 6 bulan, 9 bulan atau lebih, atau bisa juga di waktuwaktu yang lainnya. ${ }^{8}$

Ibu yang tidak mendapatkan pengetahuan dengan baik beresiko tidak melanjutkan pemberian ASI eksklusif ${ }^{9}$ karena model pembelajaran orang dewasa bersifat andragogi yang berprinsip recency. ${ }^{10}$ Dengan adanya interaksi yang rutin maka tidak menutup kemungkinan pengetahuan seseorang semakin bertambah maka peneliti tertarik untuk melakukan penelitian mengenai hubungan pengetahuan mengenai growth spurt dengan sikap ibu menyusui dalam pemberian ASI eksklusif pada bayi usia 7-10 hari di salah satu RSIA di kota Malang.

\section{METODE}

Rancangan dalam penelitian ini adalah analitik dengan study korelasi. Berdasarkan lingkup penelitiannya termasuk jenis penelitian inferensial (kuantitatif) sedangkan berdasarkan waktu pengumpulan data termasuk jenis rancangan cross sectional. Metode analitik korelasional dalam penelitian ini bertujuan untuk mengetahui hubungan pengetahuan ibu tentang growth spurt dengan sikap ibu dalam pemberian ASI eksklusif pada bayi usia 710 hari. Dalam penelitian ini menggunakan sampling insidental. Objek penelitian ini adalah Ibu menyusui yang memiliki bayi sehat usia 7-10 hari di salah satu RSIA di kota Malang Pada Tahun 2018. Karakteristik responden dalam penelitian ini diklasifikasikan berdasarkan 
usia ibu, pendidikan ibu, dan paritas ibu. Terdapat 30 responden yang ikut serta dalam penelitian ini. Intrument yang digunakan dalam penelitian ini adalah lembar kuesioner. Kemudian diuji Fisher Exact.

\section{HASIL}

Tabel 1. Tabulasi silang antara pengetahuan tentang growth spurt dengan sikap ibu menyusui pada bayi usia 7-10 hari di salah satu RSIA di kota Malang.

\begin{tabular}{|c|c|c|c|c|c|}
\hline \multicolumn{6}{|c|}{ tingkat pengetahuan * sikap Crosstabulation } \\
\hline & & & \multicolumn{2}{|c|}{ Sikap } & \multirow[b]{2}{*}{ Total } \\
\hline & & & menerima & menolak & \\
\hline \multirow[t]{6}{*}{ tingkat pengetahuan } & Baik & Count & 14 & 4 & 18 \\
\hline & & Expected Count & 10.8 & 7.2 & 18.0 \\
\hline & & $\%$ of Total & $46.7 \%$ & $13.3 \%$ & $60.0 \%$ \\
\hline & Kurang & Count & 4 & 8 & 12 \\
\hline & & Expected Count & 7.2 & 4.8 & 12.0 \\
\hline & & $\%$ of Total & $13.3 \%$ & $26.7 \%$ & $40.0 \%$ \\
\hline \multirow[t]{3}{*}{ Total } & & Count & 18 & 12 & 30 \\
\hline & & Expected Count & 18.0 & 12.0 & 30.0 \\
\hline & & $\%$ of Total & $60.0 \%$ & $40.0 \%$ & $100.0 \%$ \\
\hline
\end{tabular}

(Sumber: Data Primer Penelitian Tahun 2018)

Dari hasil crosstab diperoleh nilai expected count yang $<5$ sebanyak $25 \%$ sedangkan dengan frekuensi harapan yang kurang dari 5 tidak boleh lebih dari $20 \%$. Oleh karena itu uji chi square tidak bisa digunakan sehingga harus menggunakan uji fisher exact

\begin{tabular}{|c|c|c|c|c|c|}
\hline \multicolumn{6}{|c|}{ Chi-Square Tests } \\
\hline & Value & Df & $\begin{array}{l}\text { Asymp. Sig. (2- } \\
\text { sided) }\end{array}$ & $\begin{array}{c}\text { Exact Sig. (2- } \\
\text { sided) }\end{array}$ & $\begin{array}{c}\text { Exact Sig. (1- } \\
\text { sided) }\end{array}$ \\
\hline Pearson Chi-Square & $5.926^{\mathrm{a}}$ & & .015 & & \\
\hline Continuity Correction $^{\mathrm{b}}$ & 4.219 & & .040 & & \\
\hline Likelihood Ratio & 6.035 & & .014 & & \\
\hline Fisher's Exact Test & & & & .024 & .020 \\
\hline $\begin{array}{l}\text { Linear-by-Linear } \\
\text { Association }\end{array}$ & 5.728 & & .017 & & \\
\hline $\mathrm{N}$ of Valid Cases & 30 & & & & \\
\hline
\end{tabular}

(Sumber: Data Primer Penelitian Tahun 2018) 
Berdasarkan hasil tabulasi silang menunjukkan bahwa, ibu menyusui mempunyai pengetahuan yang baik sebanyak 14 orang (46.7\%) yang bersikap menerima, sedangkan yang berpengetahuan kurang sebanyak 4 orang (13.3\%) yang bersikap menerima.

Berdasarkan uji statistik Chi-Square antara pengetahuan ibu menyusui dengan growth spurt dengan sikap ibu menyusui terhadap bayi usia 7-10 hari didapatkan $X^{2}$ hitung $>X^{2}$ tabel (5.96 > 5.59) sehingga Ho ditolak dan $\mathrm{H}_{1}$ diterima. Pada output chi-square test diberitahukan bahwa terdapat 1 cell yang mempunyai nilai harapan yang kurang dari 5, sehingga digunakan alternatife uji Fisher Exact untuk table 2x2. ${ }^{11}$

Berdasarkan tujuan penelitian ini yaitu untuk melihat apakah ada hubungan pengetahuan tentang growth spurt dengan sikap ibu menyusui dalam pemberian ASI pada bayi usia 7-10 hari, maka exact sig. 2- sided yang nilai probabilitynya $=0,024<\alpha(0,05)$. Sehingga ada hubungan antara pengetahuan ibu menyusui dengan growth spurt dengan sikap ibu menyusui terhadap bayi usia 7-10 hari.

\section{PEMBAHASAN}

Growth spurt bayi atau percepatan pertumbuhan adalah tahapan yang umumnya terjadi selama tahun pertama anak. Tahapan ini akan mengakibatkan pertumbuhan fisik bayi bertambah signifikan, tubuh bayi bertambah berat dan panjang dan lingkar kepalanya bertambah besar, lebih cepat dari biasanya. Growth spurt bayi biasanya terjadi ketika anak berusia 2 minggu, 3 minggu dan 6 minggu. Kemudian growth spurt bisa lagi terjadi saat bayi berumur 3 bulan dan 6 bulan. Growth spurt bisa berlangsung selama 1-2 hari pada bayi baru lahir dan seminggu pada bayi yang usianya lebih besar. ${ }^{12}$ Seringkali ibu merasa cemas bahwa bayinya sering rewel dan menyusui. Para Ibu berpikir memiliki suplai ASI yang rendah. Seorang ibu dapat mengetahui perbedaan antara percepatan pertumbuhan yang sebenarnya dan masalah dengan suplai ASI sampai berapa lama tahap ini berlangsung. Percepatan pertumbuhan(growth spurt) bersifat sementara, seringkali berakhir dengan cepat. Namun, pasokan ASI yang rendah akan bertahan sampai ibu mengambil tindakan untuk meningkatkannya. ${ }^{13}$

Pengetahuan yang cukup pada ibu menyusui tentang growth spurt pada bayi dapat membuat ibu menyusui lebih tenang dan percaya diri selama proses menyusui sehingga dapat memperlancar pemberian ASI dengan menepis rasa cemas dan stress akan ketidakcukupukan stok ASI yang dimiliki 
Penelitian ini dilakukan dengan pengukuran tingkat pengetahuan ibu tentang growth spurt (percepatan pertumbuhan) dengan sikap ibu dalam menyusui bayi usia 7-10 hari yang dilakukan pada $30 \mathrm{ibu}$. Hasil penelitian diketahui jumlah ibu terbanyak berpengetahuan baik yaitu $18 \mathrm{ibu}(60 \%)$, dimana $14 \mathrm{ibu}(77,78 \%)$ yang bersikap menerima dan $4 \mathrm{ibu}(33,33 \%)$ yang bersikap menolak. Sedangkan $12 \mathrm{ibu} \mathrm{(40 \% )} \mathrm{berpengetahuan} \mathrm{buruk,} \mathrm{ibu} \mathrm{yang}$ berpengetahuan buruk dan bersikap menerima yaitu 4 ibu $(22,22 \%)$ dan yang bersikap menolak 8 ibu (66,67\%). Dari hasil tabulasi silang dapat diketahui bahwa $p$-value $<\alpha(0,024$ $<0,05)$ dan simpulkan Ho ditolak dan H1 diterima yang menyatakan bahwa ada hubungan pengetahuan tentang growth spurt (percepatan pertumbuhan) dengan sikap ibu menyusui dalam pemberian asi pada bayi usia 7-10 hari dengan tingkat kepercayaan sebesar $95 \%$.

Faktor-faktor yang mempengaruhi pengetahuan diantaranya: pendidikan; informasi; sosial, budaya, dan ekonomi; lingkungan; pengalaman; dan usia. ${ }^{14}$ Pendidikan merupakan penuntunan manusia untuk berbuat dan mengisi kehidupan yang dapat digunakan untuk mendapatkan informasi sehingga dapat meningkatkan kualitas hidup. ${ }^{15}$ Pada sebuah penelitian terdapat hubungan sikap dengan pemberian ASI eksklusif dengan nilai $[\rho$ value 0,021], dimana dengan sikap yang positif tentang manfaat ASI berpengaruh pada ibu yang bersedia menyusui ASI secara eksklusif. ${ }^{16}$ Berbagai literatur medis menetapkan manfaat menyusui, rekomendasi selama menyusui, dan variabel yang mempengaruhi durasi menyusui, tetapi keyakinan bahwa bayinya tidak puas menyebabkan banyak wanita meninggalkan menyusui bayinya. Perilaku bayi yang sering disalahartikan sebagai masalah menyusui termasuk meningkatnya tangisan, sulit untuk tenang, sulit untuk bangun, tidur yang "gelisah", sering terbangun di malam hari, atau tampaknya lalai atau tidak tertarik pada ibunya sering membuat ibu bingung akan hal ini. Dengan cara memberikan informasi pada ibu menyusui tentang pola perkembangan anak dapat memperpanjang durasi menyusui bayi sehingga membantu ibu dalam memenuhi sasaran menyusui mereka, serta meningkatkan kesehatan dan kesejahteraan ibu, bayi, keluarga, dan masyarakat. ${ }^{17}$ Dari hasil penelitian memaparkan bahwa ketika para ibu didukung dengan baik dan mengikuti rekomendasi Organisasi Kesehatan Dunia tentang menyusui, asupan susu tinggi dan meningkat seiring waktu, dan ada asupan energi yang cukup, pertumbuhan bayi yang normal, dan tidak ada perubahan nyata dalam praktik menyusui. ${ }^{18}$

Pengetahuan yang benar tentang manfaat menyusui bagi bayi dapat memunculkan suatu sikap yang positif tentang pemberian ASI. Hal ini dapat secara positif dan berkesinambungan untuk dijadikan suatu tambahan ilmu bagi ibu menyusui. Semakin baik pengetahuan yang 
dimiliki seseorang maka berdampak positif pula pada sikap sesesorang tersebut. Hal ini dikarenakan dengan bekal pengetahuan yang cukup, ibu lebih percaya diri dalam menyusui bayinya. Dengan bekal ilmu yang dimiliki ibu tentang pemberian ASI menimbulkan adanya sikap tenang, fokus dan rileks saat menyusui bayinya, sehingga ASI dapat keluar dengan lancar. ASI merupakan hak setiap bayi. Banyak faktor yang membuat ASI itu berhasil diberikan ke bayi tapi tidak sedikit pula faktor-faktor yang menghambat pemeberian ASI kepada bayi. Salah satunya pengetahuan ibu tentang growth spurt (percepatan pertumbuhan) yang sering membuat ibu bingung pada apa yang sedang dialami bayinya. Hasil penelitian ini dapat dibuktikan bahwa tingkat pengetahuan ibu tentang growth spurt berhubungan dengan sikap ibu menyusui dalam pemberian asi pada bayi usia 7-10 hari.

\section{KESIMPULAN}

Berdasarkan hasil penelitian, maka dapat disimpulkan:

a. Gambaran pengetahuan ibu menyusui tentang growth spurt adalah berpengetahuan baik sebanyak 18 orang $(60 \%)$, sedangkan yang berpengetahuan kurang sebanyak 12 orang $(40 \%)$.

b. Gambaran sikap ibu menyusui tentang growth spurt yang bersikap menerima sebanyak 12 orang $(40 \%)$ sedangkan yang menolak sebanyak 18 orang $(40 \%)$.

c. Ada hubungan pengetahuan tentang growth spurt dengan sikap ibu menyusui pada bayi usia 7-10 hari di salah satu RSIA di kota Malang, dengan $\rho$ hitung $<\alpha(0.024<0.05)$.

\section{DAFTAR PUSTAKA}

1. Sutanto, Mia. (2017). Bayi Sering Menangis - Apakah Ini Tandanya ASI Tidak Cukup?. [Internet]. Bersumber dari: <https://www.verywellfamily.com/breastfeeding-during-ababys-growth-spurt-431730>[Diakses tanggal 24 Februari 2019].

2. Naseem, A \& Mazher, N. (2016). A study to evaluate the knowledge, attitude and practices of exclusive breast feeding among primi mothers of healthy term neonates in a tertiary care hospital and predictors of failure of establishment of exclusive breast feeding in first six months. International Journal of Contemporary Pediatrics. 3(3) Augustus, pp. $810-814$

3. Rejeki, Sri. (2015). Manajemen ASI Eksklusif Pada Ibu Bekerja di BPM Ernah Kebon Kopi Kelurahan Cibereum Kecamatan Cimahi Selatan. Immanuel, Jurnal Ilmu Kesehatan Volume 9, Nomor 2, Desember 2015 ISSN 1410-234x 
4. Kemkes. (2016). Inilah Sepuluh Manfaat ASI. [Internet]. Bersumber dari: <http://www.depkes.go.id/development/site/depkes/pdf.php?id=1-16100600005> [Diakses tanggal 26 April 2019].

5. Bahriyah, Putri, dan Jaelani. (2017). Hubungan Pekerjaan Ibu Terhadap Pemberian ASI Eksklusif pada Bayi. Journal Endurance 2(2) June 2017 (113-118)

6. Anggraeni, Nurdiati, dan Padmawati. (2015). Keberhasilan Ibu Bekerja Memberikan ASI Eksklusif. Jurnal Gizi dan Dietetik Indonesia Vol. 3 No. 2 Mei 2015

7. Dinas Kesehatan Kota Malang. (2017). Profil Kesehatan Kota Malang 2015. Malang

8. Prawindarti, Lianita. (2016). Growth spurt/Percepatan Pertumbuhan [Internet]. Bersumber dari: (https://aimi-asi.org/layanan/lihat/bayi-sering-menangis) [diakses pada tanggal 10 Mei 2018]

9. Leurer M, Dietrich dan Misskey E . (2015). Be positive as well as realistic": a qualitative description analysis of information gaps experienced by breastfeeding mothers. [Internet]. Bersumber dari: <https://www.ncbi.nlm.nih.gov/ pubmed/25788970> [Diakses tanggal 24 Februari 2019]

10. Sunhaji. (2013). Konsep Pendidikan Orang Dewasa. Jurnal Kependidikan, Vol. 1 No. 1 Nopember

11. Dahlan, M. Sopiyudin. (2016). Statistik untuk Kedokteran dan Kesehatan: Deskriptif, Bivariat, dan Multivariat (Edisi 6), Epidemologi Indonesia: Jakarta

12. Nagin, Melissa Kotlen. (2018). Breastfeeding Your Baby During a Growth Spurt. [Internet]. Bersumber dari: <https://www.verywellfamily.com/breastfeeding-during-ababys-growth-spurt-431730>[Diakses tanggal 26 April 2019].

13. Robock, Karen. (2018). 3 signs your baby is going through a growth spurt. [Internet]. Bersumber dari: <https://www.todaysparent.com/baby/signs-your-baby-going-through-agrowth-spurt/> [Diakses tanggal 25 April 2019].

14. Rachmaniah, Nova. (2014). Hubungan Tingkat Pengetahuan Ibu Tentang Asi Dengan Tindakan Asi Eksklusif. Skripsi. Fakultas Kedokteran Universitas Muhammadiyah Surakarta

15. Firmansyah dan Mahmudah. (2012). Pengetahuan Dan Sikap Ibu Menyusui Terhadap Pemberian ASI Eksklusif Di Kabupaten Tuban. Jurnal Biometrika dan Kependudukan Volume 1 Nomor 1, Agustus : 62-71

16. Ardiansyah. (2010). Hubungan sikap dengan pemberian ASI Eksklusif Di Wilayah Kerja Bandar Bolang Kabupaten Pemalang 
17. Tedder, Jan. (2015). The Roadmap To Breastfeeding Success: Teaching Child Development To Extend Breastfeeding Duration. J perinat educ 24(4): 239-248

18. SB, Nielsen; JJ, Reilly ; MS, Fewtrell ; S, Eaton ; J, Grinham ; JC, Wells . (2011). Adequacy of milk intake during exclusive breastfeeding: a longitudinal study. Pediatrics Oct;128(4):e907-14 